\title{
Symbol Meaning and Dialectic Perspectives on Social Media
}

\author{
Rofiq Nurhadi $^{*}$, Edi Sunjayanto Masykuri ${ }^{2}$ \\ ${ }^{I}$ Indonesian Language and Literature Education Program Universitas Muhammadiyah Purworejo, Purworejo, \\ Indonesia \\ ${ }^{2}$ English Education Program Universitas Muhammadiyah Purworejo, Purworejo, Indonesia \\ *Corresponding author. Email: rofiq_nurhadi@yahoo.co.id
}

\begin{abstract}
In a political issue, some communities play a role and perform behind the chair. They usually have a different stance. In Indonesia, before and after a general election; president, governor, district, and sub-district election, it is involving the people, actually, become both a user and victim of a political commodity. In Islam community, there are two puritanism and culturalism thought. However, they are often used to 'get a vote' by a politician. Sometimes what they have done will make a dangerous effect, like; hate speech, scapegoating, bullying, and slowly but surely, a series of incidents of violence in religion are part of the history of the life of the nation and state, like Bombings in the Church, scapegoating of Islamic activists, and big-on the street protest. Here the issue of religion becomes intertwined with politics. The aims of the study are to know how people make some 'words' as deixis, that become a thought and how the thought influences the communities. Data taken from social media ahead of the 2019 election after tabulated will be analyzed by linguistic analysis. The result is there are symbols of language called deixis that appeared in some communities aware or not and they are used as a weapon for destructing its communities. There must be dialectic among participants to deal with in order to create the togetherness.
\end{abstract}

Keywords: pragmatics, social deixis, perspectives, communities

\section{INTRODUCTION}

People communicate with each other as exchanging expressions not only in conversation but also in sharing knowledge, culture, education, and technology. When they deliver a message as information, they usually make both monolog and dialog. [1] Then the others understand semantically, syntactically and pragmatically even in digital. Recently, everyone is free to get some information also free to share with others. They use social media, such as the internet, WhatsApp, twitter, Facebook, etc., to spread out everything they got for sharing. Sometimes it gives a negative effect on the others because there is a fabrication of fake news, intimidating, scapegoating, discrimination or hate speech. [2], [3], [4].

There are continuous gaps inside the communities caused by the political issue before and after the general election; president, governor, district, and sub-district election, actually in Islam community, they are puritanism and culturalism perspectives. The problem statements of the study are how people create words, how those words transform to the perspectives and can influence the others and negative sides of the perspectives in the community. In the perspectives of language, there is meaning in semantic, syntactic and pragmatic. In pragmatics studies, there is any connection between the speaker to a referent, speaker to the addressee, speaker to bystander and speaker to setting [5]. There is also the connection between speaker and culture [6]. Therefore, the researchers have focused on pragmatics studies to explore the deixis in a political issue, finding speakers, referent and political effects.

The purpose of the study is to know how speakers create words then transform to perspective and find out what negative effect of the perspective in that community. The study focuses on the pragmatic and sociology to find out the explanation of the phenomenon of deixis in a political issue.

\subsection{Social Deixis}

Fillmore points out that social deixis appears in the utterance between communicators, and the deixis information can be represented on the following occasions: personal deixis, e.g. pronoun; (2) various utterance platforms, e.g. honorific phrase; (3) speech context; (4) people's names, work titles and relatives; (5) utterance forms of social acts, e.g. greeting, gratitude; (6) directional information transmitted by the speaker/writer to the hearer/reader [7]. Social deixis is not merely a creature of the context of situation, but can have relevance to the broader transitional context of "society" [8]. The society here means culture. Social deixis is a social communication mirror, where speaker and hearer choose proper social deixis according to the communication object and situation, so as to reflect the social relationship and status between speaker and hearer concerned with the social status of the speaker/writer, the hearer/reader, or a third person referred to, as well as the relative social relationships between them [9]. 


\subsubsection{Social Address Forms}

Social deixis brings authority in certain context. When the speaker earns the authoritative address forms, the hearer will accept the speaker's viewpoints because of his knowledge and personal charm.

\subsubsection{Political Address Forms}

Exercise of soft power through language to influence and shape the hearers' views Speakers, are often delivered by speaker. In political discourse, some political leaders' resort to soft power to give influence to their audience and to maintain their position. They made heavily on the manipulation of the linguistic system to achieve specific goals.

\subsection{Language and political discourse}

Language is crucial for doing this as it is a 'loaded weapon' enacted by users co-operatively for various purposes [10]. Politicians recognize the role of language in achieving specific political goals.

\section{RELATED LITERATURE REVIEW}

The last research about deixis is to find out a reference in terms of communicating and knowing the social culture. [13], [14]. Person deixis in political discourse mainly the inclusive to create a stereotypical image of the American character [15].

\section{METHOD}

The method of the study is descriptive. We try to find the social deixis and going back to what is the meaning in semantic, syntactic and pragmatic. In analyzing the words, we have to know; the speaker, the referent, addressee, and background surrounding there.

\subsection{Selecting the political issue}

The issues must be a phenomenon or controversial. They have a biased meaning in semantic. The words will be personal/ communal perspectives [11].

\subsection{Finding the background surrounding the words}

The second, the researches try to focus on the background of the words which have been the social deixis. They could be the root of the word, appearing incident, history, satirical issue [12].

\section{RESULTS AND DISCUSSION}

In this study, we found five words that have fulfilled the requirement as deixis in a political issue. They have a referent, addressee and historical issues. There are two big speakers relating to the political issue; the puritanism and the culturalism in Islam communities.

Table 1. Deixis in political issue

\begin{tabular}{|lll|}
\hline No & Social Deixis & Issue \\
\hline $\mathbf{1}$ & Kafir & Political and Social \\
\hline $\mathbf{2}$ & Cadar & Political and Social \\
\hline $\mathbf{3}$ & Tahlilan & Social \\
\hline $\mathbf{4}$ & Islam Nusantara & Political \\
\hline $\mathbf{5}$ & Arab & Political \\
\hline
\end{tabular}

\subsection{Kafir}

The word kafir is from Arabic, semantically means to cover, not to express gratitude to God [16]. Historically kafir in Islam refers to people fighting what Muhammad deliver as the prophet or opposing Muhammad's religion (Islam). In the perspective of Islam puritanism, the meaning of kafir has a consequence; the rights, chance, and responsibility. They are not able to lead in the Islam community; as a president, governor, district, or even sub- district leader except in urgent condition [17]. On the contrary Islam culturalism chose the different meanings of kafir, it means non-Muslim. It has transformed Euphemia. Then it makes biased meaning. And pragmatically, it appears a prejudice gap between them; puritanism and culturalism. Puritanism thinks culturalism perspective is out of the track; not following Quran and Sunnah as references, yet culturalism thinks that puritanism is too tough and not giving a place for tolerance and tend to destructive [18].

\subsection{Cadar}

Cadar is from Indonesian, means face cloth for Muslim woman. In Islam terminology, it is called niqab. In a long discussion, there are two law perspectives of niqab; mubah and sunnah. Mubah means it can be used perspectives of niqab; mubah and sunnah. Mubah means it can be used for women and sunnah means it is included in worship.

Next, the existence of niqab is used as an identity and symbol to distinguish the quality of worship and religiosity. The puritanism said that it is a real symbol of Islam but culturalism has a different statement that niqab is a symbol of Arabs culture. So, they do not suggest women use it. When Bali bombing in 2002 and Islam phobia appeared, the world framed that terrorism came from Muslims and niqab was a symbol of terrorism [19], [20].

In a pragmatic study, perlocutionary force appearing as a reaction of the social effect, which is resistance from society for the community using niqab [21]. Whereas the puritanism is disagreed and keep consistent in their thought [22]. 


\subsection{Tahlilan}

The word tahlilan is from Arabic, means saying there is no God but Allah. The statement is called syahadat. In society, when someone has died then his or her family will manage the ceremony, it is called Tahlilan.

Tahlilan has been cored and developed a custom in the Javanese society. Starting of tahlilan is derived from the ceremony of ancestor's worship in Nusantara (old Indonesia) who are Hindus and Buddhists. Indeed, tahlilan is a form of local wisdom from the worship ceremony. This word has transformed in to deixis in two communities, tahlilan becomes a culture for Islam culturalism yet puritanism does refuse it. So, there is no tahlilan in puritanism concept.

This word is also used for political commodity to create selfidentity. Tahlilan has a referent as the culturalism. On the contrary, the puritanism does not accept tahlilan because they think it is not pure Islamic worship and they rejected Islamic innovations. They want to put back the system of the first three generations after the Prophet means the upholding of its values and principles [23].

More than three generations, both the culturalism and puritanism compromise that ritual, they try to tolerate each other. In the perspective of Muhammadiyah, the innocent tahlilan-yasinan with the premise that human beings have reached the points that will only get the reward for their own practice. They think the ritual of tahlilan incudes in the local wisdom [24].

\subsection{Islam Nusantara}

Islam Nusantara is the phrase, meaning Muslim in Indonesia. But it has transformed into deixis in political issue when used by politician to identify the community.

Relating to the history of Indonesia, we can observe that there is existence of religion phenomena, such as Hindu or Budha. These religions remain a ritual which include in Islam. The ritual tahlilan-yasinan creates the characteristic in religious, social and cultural understanding. In other words, how someone or people express the worship with syncretism perspective. The symbol is not only to fulfill the religion but it can build the social solidarity or nationality.

Culturalism call that concept is Islam Nusantara. The most important of the idea is building the social solidarity and nationality. They are not bold the pure worship [25]. On the contrary, the puritanism has different perspective in building solidarity, tolerance and nationality, they think that applied worship is more important than anything.

Puritanism has criticized the concept; they stated Islam Nusantara will be contradicted because Islam was delivered by Prophet Muhammad in Arabs. So, it shows that Indonesian Moslem accepts Islam but they modified so that changed the base fundamental. They keep Quran as a social, religious rule [26]. They also think Islam Nusantara is the form of anti-arabs.

\subsection{Arab}

The word arab semantically refers to arabs; language, people, and culture. Indonesia has the largest population moslem in the world. Arab language has become a symbol of Islam. It contributed many vocabularies in Indonesian language.

As an ethnic in Indonesia, they lived and acculturate here for a long time. They have history and influence. Religion is the fundamental base and the most difficult to change, this concept has applied by Hadhrami who brought Islam [27]. But, they got many incidents in the past because of Dutch government. Devide et Impera was the political issue that create the prejudice among minority ethnics. Since that period, many ethnics; Arabs, Chinese, Javanese, and so on did the conflict. The conflict decreased over after Indonesia got its independence.

Recently, the issue of ethnicity appears again. The politician uses it for seeing the political mapping. Pragmatically by orientalism, the use arab means a person who want to change the Indonesia ideology; Pancasila to Islam. So arab refers to puritanism not culturalism.

\section{CONCLUSION}

Pragmatics study is not only finding out the linguistic features but also historical, social, and cultural review. Social and political issue in Indonesia is an example of deixis in political issue which is interesting to discuss. In this case, the researcher finds five words including deixis in big two Islam communities; culturalism and puritanism.

Culturalism is the community who has cultural perspective in Islam. The other side, the puritanism is the other community which has pure perspective in Islam. Yet both of them often make a dialectic discussion in muamalah, fiqh, tafsir and so on. In this research, the researcher found the words kafir, cadar, tahlilan, Islam nusantara and arab in some discourses in social media. They have referent, speakers and make a context. In pragmatic study there is speech act; locutionary act, illocutionary, and perlocutionary force. Perlocutionary force appears as a reaction of the social effect. In this case, there is acceptance or resistance from society. Then this is the reason they made a bit different perspective in the same word, such Islam communities; the puritanism and culturalism. In political issue, the politicians use deixis in a speech to build the perspective; Obama did to create a stereotypical image of the American character [15]. Indonesian politicians take those words for political commodity during general election [28], [29].

\section{ACKNOWLEDGMENT}

We would like to thank this university and those who help us giving valuable guidance has been the ones. It helped us to patch this project and make it full proof success the suggestions and instructions have served as the major contributor toward the completion of the project. 
[16] N. Lailis Sa'adah, "Studi Analisis Penafsiran M. Quraish Shihab dalam Tafsir Al Mishbah dan Relevansinya dengan Toleransi di Indonesia," UIN Wali Songo, 2018.

[1] K. Ludwig, "What are group speech acts?," Language \& Communication, 2019.

[2] D. Zelina Fitriyani, E. Setia, and M. Lubis, "Speech Function and Process in Fake News," RETORIKA: Jurnal Ilmu Bahasa, vol. 5, no. 1, pp. 1-6, 2019.

[3] B. Beville, "Fake News \& the Importance of Information Literacy," 2017.

[4] P. Gil, “Gil, P. (2019). What Is Twitter \& How Does It Work? Retrieved from https:// www.lifewire.com/what-exactly-is-twitter2483331," 2019.

[5] S. C. Levingston, "Pragmatics and Socal Deixis : Reclaiming The Notion of Conventional Implicature," Research Gate, Sep. 2011.

[6] R. Wardhaugh, An Introduction to Sociolinguistics, 5th ed. 2006

[7] C. J. Fillmore, Towards a theory of deixis. The PCCLU Papers (Department of Linguistics, University of Hawaii, 1971.

[8] H. P. Manning, On social deixis., vol. 43, 1 vols. Anthropological Linguistics.

[9] S. Li and K. Li, “A Comparative Study of Social Deixis in Chinese and English from the Perspective of Rhetorical Authority," Journal for the Study of English Linguistics, vol. 3, no. 1.

[10] V. Herman, Introduction". In Dramatic Discourse: Dialogue as Interaction in Plays. London: Routledge, 1995.

[11] R. J. Podesva and D. Sharma, Research Methods in Linguistics, Second edition. New York: Cambridge University Press, 2014.

[12] W. Labov, The transformation of experience in narrative syntax. Philadelphia: University of Pennsylvania Press, 1972.

[13] D. Prasetyo, "Social Deixis In The Movie King Arthur: Legend Of The Sword 2017," Universitas Muhammadiyah Surakarta, Surakarta, 2018.

[14] Jamjuri, "Social deixis in elizabeth the golden age movie script," UIN Sunan Kalijaga, Yogyakarta, 2016.

[15] M. Hamdaoui, "The Persuasive Power of Person Deixis in Political Discourse: The Pronoun 'We' in Obama's Speeches About the 2007- 2009 Financial Crisis as an Example," presented at the The International Academic Forum, Tunisia, 2015.
[17] S. Chotban, "Hukum Memilih Pemimpin Non Muslim,” Jurnal Al Qadau, vol. 5, no. 1, 2018.

[18] Q. M. Shihab, Tafsir al Mishbah, Pesan, Kesan dan Keserasian Al- Qur'an, Jakarta : Lentera Hati,2002, h 760 volume 15. 3, vol. 15, 3 vols. Jakarta: Lentera Hati, 2002.

[19] M. Kudhori, "Kontroversi hukum cadar dalam perspektif dialektika syariat dan adat," Ijtihad, vol. 18, no. 1, pp. 33-56, 2018.

[20] R. J. Estes and M. Joseph Sirgy, "Radical Islamic Militancy and Acts of Terrorism: A Quality-of-Life Analysis," vol. 117, no. 1, 2014.

[21] M. Woodward, "Resisting Salafism and the Arabization of Indonesian Islam: a contemporary Indonesian didactic tale By Komarudin Hidayat,” 2017.

[22] M. Sukma Novri, "Konstruksi Makna Cadar Oleh Wanita Bercadar Jamaah Pengajian Masjid Umar Bin Khattab Kelurahan Delima Kecamatan Tampan

[23] N. Saat, "JOHOR AND TRADITIONALIST ISLAM: What This Means for Malaysia," Southeast Asian Affairs 2018.

[24] K. Faizah, "Kearifan Lokal Tahlilan-Yasinan Dalam Dua Perspektif Menurut Muhammadiyah," Jurnal Aqlam, vol. 3, no. 2, 2018.

[25] H. Jazimah Puji Astuti, "Islam Nusantara: Sebuah Argumentasi Beragama dalam Bingkai Kultural," INJECT, vol. 23, pp. 27-51, 2017.

[26] A. Sodiqin, Antropologi al-Qur'an, Model Dialektika Wahyu dan Budaya. Yogyakarta: ar-Ruzz Media Group, 2008.

[27] B. Najmi Muhamad, “Arabic Ethnic Houses In Kampung Arab Pasar Kliwon As The Product Of Acculturation," Arsitektura, vol. 16, no. 1, pp. 25-38, 2018.

[28] "Mahfud: Tidk Perlu Ada Pelarangan Penyebutan Kafir," PortalIslam.id.

[29] "Hadiri konferensi toleransi di Malta, Yenny Wahid malah diributkan soal kerudung yang 'tidak rapat," BBC News, 08-Nov-2017. Pekanbaru," Jom Fisip, vol. 3, no. 1, 2016. 